\title{
Exoneration in Sweden
}

\author{
Is It Not about Time to Reform the Swedish Model?
}

\section{Dennis Martinsson*}

\begin{abstract}
This article reviews exoneration in Sweden, with a focus on the procedure of applying for exoneration. First, it highlights some core features of Swedish criminal procedural law, necessary to understand exoneration in the Swedish context. Secondly, it outlines the possibilities in Swedish law to apply for exoneration, both in favour of a convicted person and to the disadvantage of a previously acquitted defendant. Thirdly, it identifies some challenges with the current Swedish model of administering applications for exoneration. Fourthly, it argues that the current system should be reformed by introducing into Swedish law a review committee that administers applications for exoneration.
\end{abstract}

Keywords: wrongful convictions, extraordinary legal remedy, exoneration, exoneration in Sweden

\section{Introduction}

Sweden is renowned for a legal system that respects the rule of law. ${ }^{1}$ This respect is visible in some of the core characteristics of the Swedish criminal justice system. As with all the other Scandinavian countries, Sweden does not allow plea bargaining, and the state provides a public defence counsel whose costs are covered by state funds. ${ }^{2}$ The defence counsel is also appointed at a very early stage in the pre-trial investigation and successively

* Dennis Martinsson is Assistant Professor in the Department of Law of Stockholm University in Sweden.

1. Sweden, for example, often ranks well internationally in regard to the rule of law, see, e.g., The World Justice Project Rule of Law Index 2020, available at https://worldjusticeproject.org/sites/default/files/docu ments/WJP-ROLI-2020-Online_0.pdf (last visited 17 February 2021), which ranks Sweden among the top four countries in the world.

2. The strong main rule is that the state will cover the costs of the public defence counsel (Swedish Code of Judicial Procedure, Chapter $21 \mathrm{Sec}$ tion 10). Theoretically, if the defendant is convicted, he or she shall reimburse the state for the public defence counsel's litigation costs. The reimbursement is limited to litigation costs listed in the Swedish Code of Judicial Procedure, Chapter 31 Section 1. A convicted person might also reimburse the costs of the injured party's counsel (målsägandebiträde) and the special advocate for children (särskild företrädare för barn). However, in practice, the defendant is not required to pay more of the defence costs than he or she would have to pay as the legal aid charge, if legal aid had been granted according to the Legal Aid Act. The legal aid charge reimbursement will be decided according to the defendant's economic situation. If the defendant lacks economic resources, the public defence counsel's costs will be covered entirely by the state. The defendant can, of course, hire a private defence counsel, in which case the defendant covers the costs him- or herself. receives information concerning the case from the prosecutor. Other signs of the respect for the rule of law are that the prosecutor should indict a person only if there are sufficient reasons to believe that he or she committed the crime and if the assessment is that an indictment will result in a guilty verdict. Further, the prosecutor has the burden of proof and a conviction requires that the evidence prove beyond reasonable doubt that the defendant committed the crime. Another feature is that Swedish law offers rather extensive possibilities for a defendant who has been convicted by a district court to appeal against the judgment. ${ }^{3}$ Thus, Sweden's several legal safeguards ensure that criminal law cases are treated fairly and justly.

Yet in recent years several cases of wrongful conviction have been exposed in Sweden. A common denominator in these cases is that the wrongful convictions have been disclosed by journalists who have spent - at least regarding some cases - years researching and scrutinising these cases. ${ }^{4}$ Eventually, applications for exoneration

3. Three instances in Sweden decide on criminal cases: the district court the court of appeal and the Supreme Court. There are forty-eight district courts and six courts of appeal. From the Swedish Code of Judicial Procedure, Chapter 51, it follows that Swedish law offers rather extensive possibilities for the defendant to appeal against a pronounced judgment by a district court. As a main rule, a review permit is not needed here. However, in order to bring a case to the Supreme Court, a review permit is needed, which is approved only if the case is "of importance for the guidance of the application of law" or "if there are extraordinary reasons for such a determination, such as that grounds exist for relief for substantive defects or that a grave procedural error has occurred or that the result in the court of appeal is obviously due to gross oversight or to gross mistake" (Swedish Code of Judicial Procedure, Chapter 54 Section 10).

4. The most (in)famous case is Thomas Quick, who later changed his name to Sture Bergwall. During the 1990s he confessed to numerous murders in Sweden and Norway and was convicted of eight murders. But he was later found not guilty of any of the murders to which he had confessed. The journalist Hannes Råstam showed in three SVT documentaries, screened in 2008 and 2009, that the confessions were false and a product of maltreatment in the psychiatric ward where Quick was being held. The documentaries also showed that Quick had gained information from the prosecutor and the police, enabling him to provide details in his confessions. He received information directly from the people involved in the pre-trial investigation. Therefore, the evidence presented to the courts in each case was false. The Quick case prompted a general debate and discussion among jurists in Sweden. A government inquiry scrutinised each of the cases, see SOU 2015:52, with a summary in English at 23-8. Another wrongful conviction disclosed after investigation by a journalist is the case of Samir Sabri, who at the age of fifteen confessed to the murder of his stepmother. He was convicted of this crime. In an investigating podcast entitled \#Fallet, broadcast in 2015, journalist Anders Johansson found that Samir could not possibly have committed the murder and that he had confessed so that his father would not serve time in prison. Samir Sabri's application for 
were filed in these cases, all of which were approved. The result was a reopening, ending in acquittal of persons who had previously been convicted.

Swedish law recognises two other legal remedies besides exoneration $^{5}$ for a post-conviction revision: restoration of expired time and grave procedural error. However, this article focuses solely on exoneration. ${ }^{6}$ This is because the legal grounds serve different purposes; exoneration serves to correct judgments that are materially incorrect, while the function of grave procedural error is to correct judgments that are procedurally incorrect. The purpose of restoration of expired time is to regain an applicant's lost right so that he or she can use an ordinary legal remedy, for example the possibility to appeal. Thus, these three extraordinary legal remedies have very little in common. Another reason for excluding restoration of expired time and grave procedural error is that they presuppose that an application has been filed within certain time frames, thereby limiting the possibility to invoke these legal remedies. Also, applications for exoneration are far more common in criminal law cases than are the other two extraordinary legal remedies.

Moreover, scholarly publications on exoneration in Sweden are rather scarce, and research on exoneration in Swedish criminal procedural law is in the nature of a blank spot. ${ }^{7}$ Until recently, the main scholarly work consisted of a $\mathrm{PhD}$ dissertation published in $1959 .{ }^{8}$ However, an ongoing $\mathrm{PhD}$ project in criminology ${ }^{9}$ and an ongoing $\mathrm{PhD}$ project in procedural law focus on exoneration. ${ }^{10}$ The subject was also recently analysed in a published $\mathrm{PhD}$ thesis in jurisprudence, which focused

exoneration was approved, resulting in a reopening of the case. He was eventually found not guilty.

5. Swedish law also contains a similar, but separate, provision for exoneration in civil law cases, see Swedish Code of Judicial Procedure, Chapter 58 Section 1. The present review focuses solely on the provision for exoneration in criminal law cases.

6. 'Exoneration' is the translation of the Swedish word resning, which is sometimes translated as 'new trial', 'review' or 'relief for a substantive defect'. The Swedish word resningsansökan, i.e. the application for exoneration, is sometimes also translated as 'petition for a new trial' or 'application for a substantive defect'. For the purposes of this article and for consistency, the terms 'exoneration' and 'application for exoneration' will be used. However, using 'exoneration' is not unproblematic. As will be seen later, Swedish law allows an application for exoneration to the benefit of a convicted person and to the disadvantage of a previously acquitted defendant. It is also possible that an application concerns only the sentence and not the question of whether the defendant is guilty of the crime(s) committed. Thus, the concept of exoneration in Sweden is wider than a petition for a new trial to the benefit of the defendant. Using a more complicated phrasing than 'exoneration', when referring to all aspects concerning the procedure of applying for exoneration, would indeed be rather ungainly.

7. P.O. Träskman, 'Rätten till riktig resning - En fråga försummad av forskningen?', 92 Nordisk Tidsskrift for Kriminalvidenskab 249 (2005).

8. T. Cars, Om resning i rättegångsmål (1959).

9. Project conducted by Sara Hellqvist, Stockholm University. As a part, she has published an analysis of data on cases of exoneration collected during one year, see S. Hellqvist, 'The Narrow Road to Exoneration the Incidence, Characteristics and Outcomes of Wrongful Conviction Claims in Sweden over a One-Year Period', 5 Bergen Journal of Criminal Law and Criminal Justice 131 (2017).

10. Project conducted by Christina Kjellson, Uppsala University. mainly on the concept of confirmation bias. ${ }^{11}$ Besides the two published scholarly theses, there is literature published by legal academics that provide an overview of the Swedish regulations on exoneration. In addition, the applicable Swedish provisions on exoneration have remained practically unchanged since 1940 . The lack of legal research and the lack of legal reform provide yet another reason to focus on exoneration.

The main purpose of this article is twofold: to review the legal framework for exoneration in Sweden and to discuss whether there is a need for a reform of the current Swedish procedure for applications for exoneration. The review shows that an application for exoneration in Sweden can be based on several legal grounds and that it can be filed either in favour of a convicted person or to the disadvantage of a defendant who has previously been acquitted. In the latter case, a time frame limits the possibilities for filing an application. Further, some challenges regarding the current Swedish model of handling applications for exoneration are identified. Thus, the review suggests that Sweden should start offering official and annual statistics on the number of applications filed and that Sweden should consider implementing a different procedure for reviewing applications by introducing a review committee.

\section{Legal Framework for Revision When Invoking Exoneration}

\subsection{Basic Features to Understand Exoneration in the Swedish Context}

\subsubsection{Balancing the Principle of Firmness and the Principle of Truth}

In Swedish law exoneration is categorised as an extraordinary legal remedy, ${ }^{12}$ meaning that it can be invoked only if a court has pronounced a legally binding judgment. ${ }^{13}$ Thus, exoneration is relevant only when the 'ordinary' legal remedies - i.e. the possibility to appeal have been exhausted. Exoneration as a legal ground for post-conviction revision has existed in Swedish law since (at least) the seventeenth century. ${ }^{14}$ The current

11. Project conducted by Moa Lidén, Uppsala University, who defended her PhD thesis in 2018. As a part, she published a co-written article on confirmation bias, where the matter of exoneration was discussed to some extent; see M. Lidén, M. Gräns \& P. Juslin, 'Self-Correction of Wrongful Convictions: Is There a "System-level" Confirmation Bias in the Swedish Legal System's Appeal Procedure for Criminal Cases? Part II', 17 Law, Probability and Risk 337 (2018).

12. This follows from the title of the Swedish Code of Judicial Procedure, Chapter 58: "Extraordinary remedies", in which the rules of exoneration are stated.

13. According to Swedish criminal procedural law, this simply means that the judgment can no longer be appealed against; see the Swedish Code of Judicial Procedure, Chapter 30 Section 9 para. 1.

14. For a thorough overview of the historical development of the extraordinary legal remedies (including exoneration) in Sweden, see Cars, above n. 8, at 48-93. Note, generally, that the judicial system in Sweden - like 
provisions regulating exoneration entered into force in 1940. Despite minor changes, these provisions have remained largely unchanged since then. ${ }^{15}$

From a normative point of view, an application for exoneration is granted extremely rarely. The rationale behind this position is the principle of firmness, ${ }^{16}$ according to which a legally binding judgment by a court in a criminal law case should not be reconsidered. This also ensures that the legal system is reliable in the sense that a case will not be brought before a court again. One might claim that the principle of firmness is an expression of formal fairness. However, this contrasts with the principle of truth, ${ }^{17}$ which means that it is important that a judgment in a criminal law case is correct from the perspective of material fairness. According to this principle, the law must offer a possibility to quash wrongful convictions and a possibility for a review of wrongful convictions; otherwise, the public might lose their trust in the legal system. Therefore, the design of the regulation of exoneration needs to find the right balance between the principle of firmness and the principle of truth. ${ }^{18}$ In Swedish criminal procedural law, the rules on exoneration represent a compromise between these two principles since they ensure that a formally correct final verdict might (in rare cases) be reopened in order to secure material fairness. ${ }^{19}$

To understand the legal framework on exoneration in Swedish law, note that an application for exoneration is viewed as a petition for reopening a case. As a main rule, if an application is approved, a new trial should be held. At the succeeding trial, the question of whether the defendant is guilty is tried anew.

\subsubsection{The Concept of the Binding Effect of a Fudgment and Its Relation to Exoneration}

In Swedish criminal procedural law, res judicata (the subject matter has already been adjudicated) and ne bis in idem (prohibition against trying someone twice for the same act) are viewed as two separate grounds for procedural hindrance. An important expression of this is the

that in many other European countries - was reformed in the seventeenth century to include more modern approaches to the judiciary. One example of the modernisation was the creation of a more distinct division of different court levels. This also created a need for provisions regulating the possibilities for a post-conviction revision. Previously, Swedish law offered other extraordinary legal remedies that were similar to the present-day provisions on exoneration.

15. See the travaux préparatoires SOU 1926:32, at 231-44; SOU 1926:33, at 135-41; SOU 1938:44, at 65-75, 572-82; prop. 1939:307; NJA II 1940 s. $147-86 ;$ NJA II 1943 s. 725-39. Some minor changes were made in 1975, see the travaux préparatoires: prop. 1975:78, JuU 1975:22; NJA I| 1975 s. 671, and in 1985, see the travaux préparatoires: prop. 1987/88:23, JuU 1987/88:15; NJA II 1987 s. 676. See also, e.g., Supreme Court case NJA 2001 s. 687, at 689, where the Court stated that the provisions regarding exoneration have remained unchanged since 1940.

16. In Swedish: orubblighetsprincipen

17. In Swedish: sanningsprincipen.

18. On the matter of balancing these two principles in both the legislature and the judiciary, see Cars, above n. 8, at 173-6.

19. Cf. Supreme Court case NJA 1998 s. 321, at 322. Note that the balance between these two principles differs, depending on whether an application for exoneration is filed in favour of a convicted person or to the disadvantage of a defendant who has previously been acquitted. concept of the binding effect of a judgment, meaning that an adjudicated case cannot be tried anew. ${ }^{20}$ Thus, the binding effect of a judgment hinders a new trial. However, if a court approves an application for exoneration, it quashes the binding effect in the sense that the previous judgment no longer hinders a new trial. Note that an approval does not quash the original judgment.

The concept of the binding effect of a judgment has been discussed mostly in the literature. ${ }^{21}$ The discussion has focused mainly on the following criteria: the course of events, the time and place of the act and against who or what the act was committed. It has been suggested that the criteria that constitute 'the (same) act' in the Spedish Code of Fudicial Procedure, Chapter 30 Section 9 para. 1 , needs to coincide with the provision on exonera-

20. See the Swedish Code of Judicial Procedure, Chapter 30 Section 9 para. 1: "Once the time for ordinary means of appeal has expired, the issue of the defendant's criminal liability for the act which was determined by the judgment may not be taken up again for adjudication." It should be noted that the concept of the binding effect of a judgment is wider than the indictment, since it, for example, includes elements of the crime that were not tried and includes cases where the prosecutor decides to circumscribe the indictment; see the travaux préparatoires SOU 1938:44, at 472; K. Olivecrona, Rättegången i brottmål enligt RB (1968), at 159-60; T. Bylund, 'Kioskinbrottet och rättskraftsspöket. En strip-tease i sex moment', in A. Agell, R. Boman \& N. Jareborg (eds.), Process och exekution. Vänbok till Robert Boman (1990) 41, at 46-53. Further, the concept of the binding effect is also relevant in relation to the possibility for the prosecutor to, during the ordinary proceeding, file a prosecution adjustment (justering av åtal) respectively file an amendment of the indictment (ändring av åtal). To put it simply, Swedish criminal procedural law allows the prosecutor to rather easily file a successful prosecution adjustment (Swedish Code of Judicial Procedure, Chapter 45 Section 5 para. 3) but regulates the possibility for an amendment of the indictment restrictively (Swedish Code of Judicial Procedure, Chapter 45 Section 5 para. 1), since the main rule is that an amendment is not allowed after the prosecutor has indicted someone. This means that circumstances that could have been included in the (original) trial by filing an amendment of the indictment, will be covered by the binding effect of the (original) judgment. Thus, it hinders a second trial. See further on this matter, e.g., P.O. Ekelöf, H. Edelstam \& M. Pauli, Rättegång. Andra häftet (2015), at 167-70. Note that the Swedish Code of Judicial Procedure, Chapter 30 Section 9 para. 1, needs to be interpreted in line with European norms (i.e. res judicata and ne bis in idem) that follow from, e.g., the practice of the EU Court of Justice and the European Court of Human Rights. However, considering that the concept of the binding effect of a judgment is comprehensive, it is difficult to imagine that the application of the Swedish provision in this regard would infringe the European norms. For an overview of the Swedish concept of binding effect in relation to European norms, see, e.g., P.O. Ekelöf, S. Andersson, H. Bellander, T. Bylund, H. Edelstam \& M. Pauli, Rättegång. Tredje häftet (2018), at 203-4, 218-21. See also Supreme Court case NJA 2007 s. 557, where the Court referred to EU case law when it determined the binding effect in a case of drug offence.

21. The concept of the binding effect is rather complex, as it raises questions about the interpretation of several provisions in the Swedish Code of Judicial Procedure that uses the same phrasing. One cannot simply understand the meaning of the concept solely from one provision. The matter is discussed further in, e.g., Ekelöf et al. (2018), above n. 20, at 203-21; P. Fitger et al., Rättegångsbalken (4 December 2019, Norstedts Juridik), commentary to the Swedish Criminal Code on Judicial Procedure, Chapter 30 Section 9; L. Welamson, Om brottmålsdomens rättskraft (1949); Olivecrona, above n. 20, at 145-74; T. Andersson, 'Brottmålsdomens rättskraft', in B. Lindell, H. Eklund, P. Asp \& T. Andersson (eds.), Straffprocessen (2005) 267, at 267-75; T. Andersson, 'Straffprocessuell rättskraft, särskilt i narkotikamål: Rättskraftsspöket går igen!', in B. Lindell and T. Andersson (eds.), Vänbok till Torleif Bylund (2003) 9 , at 9-51; Bylund, above n. 20, at 41-69. 
tion to the disadvantage of the defendant. ${ }^{22}$ Otherwise, the concept of the binding effect would collide with the rationale of the provision on exoneration to the disadvantage of the defendant. ${ }^{23}$ Consequently, this reasoning suggests that the concept of the binding effect indirectly demands that the prosecutor have a solid case before indicting someone. If it were possible for the prosecutor to 'save' evidence to a later trial, it would create a risk that the pre-trial investigation is not conducted as thoroughly as possible. ${ }^{24}$ The prosecutor should therefore include alternative or cumulative elements of the crime when indicting someone. ${ }^{25}$

In conclusion, the effect of res judicata extends beyond the indictment in the original trial. Additionally, the concept of the binding effect of a judgment has direct implications for exoneration. Since this concept is comprehensive in Swedish criminal procedural law, it significantly narrows the possibility for a court to approve an application for exoneration - particularly if the application is filed to the disadvantage of a previously acquitted defendant. In that case, the concept of the binding effect could be viewed as a (strong) legal safeguard for the individual, protecting him or her from a new trial. ${ }^{26}$

\subsection{Grounds for Revision When Invoking Exoneration}

Swedish law offers two provisions - applicable in two different situations - for a post-conviction revision in criminal law cases when the applicant invokes exoneration. ${ }^{27}$ An application for exoneration can be filed either in favour of a convicted person (Spedish Code of Fudicial Procedure, Chapter 58 Section 2) or to the disadvantage of a defendant who has previously been acquitted (Smedish Code of Fudicial Procedure, Chapter 58 Section 3). These two main categories provide various subcategories of legal grounds for reopening the case. Since the prerequisites for these two main categories differ to some extent, they are presented separately.

When an application for exoneration is filed to the benefit of a previously convicted person, Swedish law recognises five legal grounds. They are regulated in the Smedish Code of Fudicial Procedure, Chapter 58 Section 2, which states:

22. This idea of coinciding the meaning of 'the (same) act' in the Swedish Code of Judicial Procedure, Chapter 30 Section 9 para. 1, and the rule on exoneration to the disadvantage of a previously acquitted defendant was first presented by Lars Welamson; see Welamson, above n. 21, at 135-51. See also Ekelöf et al. (2018), above n. 20, at 206, 213-17; Andersson (2005), above n. 21, at 269-70. On the possibilities to file an application to the disadvantage of a previously acquitted defendant, see Section 2.2

23. Welamson, above n. 21, at 139

24. Welamson, above n. 21, at 54-55, 144-45, 262. See also Andersson (2005), above n. 21, at 270; Ekelöf et al. (2018), above n. 20, at 206

25. See, e.g., K. Olivecrona, 'Några rättsfall om ändring av åtal och res iudicata i brottmål', 42 Svensk juristtidning, 1, at 6 (1957).

26. Beside the argument of providing a legal safeguard, economic reasons also motivate this position; see, e.g., the travaux préparatoires: SOU 1938:44, at 65 .

27. The Swedish Constitution states that exoneration is a legal remedy that ensures a possibility for a post-conviction revision; see Instrument of Government, Chapter 11 Section 13.
After a judgment in a criminal case has entered into final force, relief for a substantive defect may be granted for the benefit of the defendant:

1. if any member of the court, an officer employed at the court, or the prosecutor, with respect to the case, is guilty of criminal conduct or neglect of official duty, or if an attorney, legal representative, or defence counsel is guilty of an offence with regard to the case, and the offence or neglect of duty can be assumed to have affected the outcome of the case,

2. if any legally qualified judge or the prosecutor has been disqualified and it is not plain that the disqualification has been without importance as to the outcome of the case,

3. if a written document presented as evidence was forged or a witness, expert, or interpreter gave false testimony and the document or statement can be assumed to have affected the outcome,

4. if a circumstance or item of evidence that was not presented previously is invoked and the its [sic!] presentation probably would have led to the defendant's acquittal or that the offence would have been linked to a sanction provision milder than that applied, or if in view of the new matter and other circumstances, extraordinary reasons warrant a new trial on the issue whether the defendant committed the offence for which he was sentenced, or

5. if the application of law forming the basis of the judgment is manifestly inconsistent with a statutory provision. ${ }^{28}$

The most interesting of these legal grounds is the one concerning new evidence or new circumstances, particularly since it is presumably the most commonly invoked legal ground when applying for exoneration. ${ }^{29}$ Therefore, the present focus is on exoneration due to new evidence or new circumstances. This legal ground is usually divided into the main rule and the supplemental rule.

According to the main rule, an application for exoneration should be granted when the applicant presents a new circumstance or new evidence that was not invoked at the previous trial and that would probably have resulted in either an acquittal or a milder sentence. By new circumstance or new evidence is meant any fact

28. This is the English translation offered by the Swedish Government, see Ds 1998:65, at 336, available at www.regeringen.se/49bb67/ contentassets/5503f73d320b4de5bb521dd7ee07500a/the-swedishcode-of-judicial-procedure (last visited 17 February 2021).

29. This is often stated in Swedish criminal procedural literature; see, e.g., L. Welamson and J. Munck, Processen i hovrätt och i Högsta domstolen. Rättegång VI (2016), at 193; Fitger et al., above n. 21, commentary to the Swedish Code on Judicial Procedure, Chapter 58 Section 2; H. Eklund, 'Processen i hovrätt och i Högsta domstolen', in B. Lindell, H. Eklund, P. Asp \& T. Andersson (eds.), Straffprocessen (2005) 279, at 338; P.O. Ekelöf and H. Edelstam, Rättsmedlen (2008), at 192. See also the travaux préparatoires, prop. 1939:307, at 19; SOU 1938:44, at 74, which emphasises that the most common legal ground for exoneration is assumed to be new circumstances or new evidence. 
that might affect a court's assessment of the presented evidence. ${ }^{30}$ Thus, both dispositive fact and evidentiary fact can be invoked when filing an application. ${ }^{31}$ There might also be a peripheral circumstance that weakens the reliability of one fact in a chain of evidence. ${ }^{32}$

The evidence presented must be completely new, in the sense that it was not presented before a court during the main hearing. ${ }^{33}$ Consequently, it is, for example, still considered a new circumstance or new evidence if it was present in the pre-trial investigation but not invoked at the main hearing. ${ }^{34}$ This is also the case if the new circumstance or new evidence has been invoked in an appeal to a higher court but the appeal was not granted ${ }^{35}$ or has been invoked in a previous application for exoneration, which was denied. ${ }^{36}$

The requirement that the new circumstance or new evidence would probably have resulted in either an acquittal or a milder sentence evidently opens the way for hypothetical reasoning. ${ }^{37}$ When deciding whether the new circumstance or new evidence would 'probably' have resulted in a more favourable outcome for the defendant, the court should not re-examine the evidence. Instead, the court that decides whether an application for exoneration should be granted needs to assess what the outcome of the previous trial would have been if the evidence had been presented then. Thus, the assessment should - theoretically - focus on how the original court would have reasoned if the new circumstance or evidence had been presented before that court. However, the new circumstance or evidence should not be viewed as isolated from what had previously been presented but must be considered in the light of the original evidence. The new evidence must be of such weight that it questions the previous verdict. The matter of what weight the new circumstance or evidence

30. See the travaux préparatoires: prop. 1939:307, at 10, 19, 28; SOU 1938:44, at 74

31. See, e.g., Cars, above n. 8, at 152-69; Ekelöf and Edelstam, above n. 29, at 192; Welamson and Munck, above n. 29, at 199-200; B. Bengtsson, 'Resning i brottmål vid synnerliga skäl', in A. Agell, R. Boman \& N. Jareborg (eds.), Process och exekution. Vänbok till Robert Boman (1990) 1, at 6-7.

32. See the travaux préparatoires: SOU 1938:44, at 74. See also Bengtsson, above n. 31, at 6 .

33. See the travaux préparatoires: SOU 1938:44, at 573

34. Ibid., at 573,575

35. See, e.g., Supreme Court case NJA 1998 s. 148. Cf. Supreme Court, decision, 29 December 2016, reference number Ö 5257-15; Supreme Court, decision, 21 March 2018, reference number Ö 4066-17, where the Supreme Court in each case granted the application for exoneration. In these two cases, previous applications had been filed but not granted. The reason that the applicants were able to successfully file a new application was a combination of new circumstances/evidence and of what had been referred to in the previous applications. See further, in Section 3.2.

36. See, e.g., Cars, above n. 8, at 171. See, however, the Esa Teittinen case and the Kaj Linna case, presented in Section 3.2. In the Esa Teittinen case, evidence presented in the first application for exoneration was not considered new in the second (and successful) application, while in the Kaj Linna case it seems that the two previous unsuccessful applications for exoneration had some bearing when the Supreme Court granted his third application.

37. See, e.g., Welamson and Munck, above n. 29, at 205; Bengtsson, above n. 31, at 2 . should be given is difficult to answer, since this depends on the circumstances of the individual case. Given these difficulties, one has to rely on guidelines. Generally, the stronger and more reliable the original evidence was, the greater the strength of the new circumstance or evidence must be for the court to grant the application. Conversely, the less convincing the original evidence was, the less weight the new circumstance and evidence needs to have. ${ }^{38}$ The latter is obviously questionable, because if the evidence in the original trial that resulted in a conviction was less convincing, the court should probably not have been able to find the defendant guilty. The general statement above was made in the travaux préparatoires and is not developed with examples. Potentially, this could occur if the original trial were held many decades ago, when the courts applied a different standard for assessing the evidence. Another possible example could be a conviction that was based only on circumstantial evidence. In these situations, it is understandable that, comparatively, the new circumstance or evidence underlying an application for exoneration can be of lesser weight.

An incorrect assessment in the original trial of the (original) evidence is no reason for granting an application for exoneration. ${ }^{39}$ Additionally, it is not enough that mitigating circumstances are present or that the new circumstance or new evidence would result in a milder sanction within the same range of punishment as that previously applied by the original court. ${ }^{40}$

The supplement rule enables the court to grant an application for exoneration in cases where the requirements of the main rule are not met, but where, considering what the applicant is invoking and other circumstances regarding the case, there are extraordinary reasons to reopen the case. The Swedish Supreme Court has repeatedly stated that the supplement rule should be applied restrictively. ${ }^{41}$ That opinion is also expressed in the literature. ${ }^{42}$ However, some authors emphasise that it is difficult to draw general conclusions from the Supreme Court cases regarding the supplement rule but that it is possible to conclude that it follows from the case law of the Supreme Court (before 1990) that the supplement rule is not always applied as strictly as was originally intended. ${ }^{43}$

An application based on the supplement rule may be granted when the circumstances concerning the case are

38. These - perhaps obvious - starting points were stated in the travaux préparatoires when the current provision was introduced into Swedish law; see prop 1939:307, at 19, 28; SOU 1938:44, at 74.

39. See, e.g., Welamson and Munck, above n. 29, at 205.

40. See the travaux préparatoires prop. 1939:307, at 13; SOU 1938:44, at 575. See also Ekelöf and Edelstam, above n. 29, at 192; Fitger et al., above n. 21, commentary to the Swedish Code on Judicial Procedure, Chapter 58 Section 2.

41. See, inter alia, the following Supreme Court cases: Supreme Court, decision, 27 December 2019, reference number Ö 5485-19, para. 12; NJA 2018 s. 163 , para. 25 ; NJA 1992 s. 625 , at 626

42. See, e.g., Cars, above n. 8, at 224-6; Bengtsson, above n. 31, at 4. See also Welamson and Munck, above n. 29, at 207-8

43. Bengtsson, above n. 31, at 16. Note that Bengtsson's article focused only on cases from the Swedish Supreme Court, which until 1988 was the only court that decided on applications for exoneration. 
not enough to conclude that they would probably have led to a different assessment concerning whether the defendant was guilty but are still enough to cause doubt about the outcome of the previous judgment. That might be the case if considerable dissenting opinions existed between, for example, the district court and the court of appeal. ${ }^{44}$ However, it is not enough to grant an application based on this rule if a case has received a great deal of media attention or scrutiny. ${ }^{45}$

The requirement that the supplement rule should be applied when there are 'extraordinary reasons' to reopen the case means that the defendant must have been found guilty of a grave crime. ${ }^{46}$ No guideline is available to clarify - in this context - what is meant by a grave crime. However, in extremely rare cases an application for exoneration might be granted even if the defendant had received a rather mild sentence. ${ }^{47}$

If an application is filed to the disadvantage of a defendant who has previously been acquitted, the Smedish Code of Fudicial Procedure, Chapter 58 Section 3, stipulates the following alternative requirements:

After a judgment in a criminal case has entered into final force, relief for a substantive defect may be granted to the detriment of the defendant:

1. if any such condition of the kind referred to in Section 2, clause 1 or 3 , existed and this can be assumed to have contributed to the defendant's acquittal or that the offence was linked to a sanction provision substantially milder than the one that should have been applied, or

2. if the offence is punishable by imprisonment for a term exceeding one year and some circumstance or item of evidence that was not presented previously is invoked and its presentation probably would have led to conviction of the defendant for the offence or that the offence would have been linked with a sanction provision substantially more severe than the one applied.

Relief for a substantive defect may not be granted on the basis stated in clause 2, unless the party shows probable cause that he was unable to invoke the circumstance or item of evidence in the court that pronounced the judgment or on appeal therefrom or he otherwise had a valid excuse for failing to do so. ${ }^{48}$

44. See the travaux préparatoires: prop. 1939:307, at 28; SOU 1938:44, at 75,575 . However, it has been questioned whether it would be of any significance. It might, however, illustrate that the case raised difficult questions regarding the evidence, see Bengtsson, above n. 31, at 14.

45. See, e.g., Bengtsson, above n. 31, at 15-16. Note, however, the mention above in Section 1, that recent applications for exoneration have been granted in several cases following disclosure by journalists. Thus, Bengtsson's 1990 claim may have less bearing than then. Nowadays, it seems that that the work of a journalist is often needed for enabling a previously convicted person to successfully apply for exoneration.

46. See the travaux préparatoires: prop. 1939:307, at 28; SOU 1938:44, at 575.

47. See, e.g., the Supreme Court case NJA 1980 s. 550.

48. This is the English translation offered by the Swedish government; see Ds 1998:65, at 336-7, available at www.regeringen.se/49bb67/ contentassets/5503f73d320b4de5bb521dd7ee07500a/the-swedishcode-of-judicial-procedure (last visited 17 February 2021).
It is highly unusual for an application for exoneration to be based on this provision, and when an application is filed, the most common legal basis is new evidence or new circumstances. ${ }^{49}$ Although this provision states a possibility to apply for exoneration to the disadvantage of an acquitted defendant, the criteria stated in the provision limit the possibility to do so. Generally, the requirements for granting an application based on the provision are stricter than those for applying to the benefit of the defendant. ${ }^{50}$

In addition, an application that is based on this provision must be filed within one year after the situation underlying the application became known to the applicant (Spedish Code of Fudicial Procedure, Chapter 58 Section 4 para. 2). The Supreme Court has stated that the time limit of one year should be counted in relation to every item of new evidence or new circumstance. ${ }^{51}$

Thus, the time frame and other requirements - for example, that a conviction should have resulted in a substantially more severe sanction and the limitation to rather severe crimes - imply that applications for exoneration to the disadvantage of a previously acquitted defendant are regulated rather strictly.

However, a proposal published in 2018 in the Ministry Publications Series suggests that the possibilities to apply for exoneration to the disadvantage of a previously indicted person should be extended. The proposal suggests the introduction of a new legal ground into Swedish law, enabling an application to the disadvantage if new evidence shows that the previously indicted person was older than what was claimed in the original trial, thus resulting in a reduced sentence owing to the age of the convicted. A corresponding new legal remedy is also proposed in relation to an application for exoneration in favour of a previously convicted person; if new evidence shows that the defendant was actually younger than assumed at the original trial. ${ }^{52}$ The proposal has been

49. See, e.g., Ekelöf and Edelstam, above n. 29, at 187-8.

50. See, e.g., the travaux préparatoires prop. 1939:307, at 13, 20; SOU 1938:44, at 74-5, 575; the following Supreme Court cases: NJA 1998 s. 321; NJA 2001 s. 687; NJA 2016 s. 851; NJA 2013 s. 931, at 932-3, paras. 14, 22; NJA 2020 s. 518, para. 23 and Supreme Court, decision, 17 December 2020, reference number Ö 936-20, para. 15. This position is also expressed in the Swedish criminal procedural literature; see, e.g., Cars, above n. 8, at 215-16.

51. See, e.g., Supreme Court case NJA 1998 s. 321 . See, however, Supreme Court case NJA 2013 s. 931, where witness evidence known to the prosecutor more than a year before an application to the disadvantage of a previously acquitted defendant was filed. However, the Supreme Court stated that the witness evidence had come in another light, particularly since it brought new insights to the finding of the (new) main evidence, i.e. the body of the victim had been found. Since the prosecutor filed the application within one year from this discovery, the witness evidence was considered new. The Supreme Court has recently stated that, in a case concerning new DNA analysis, it is necessary to interpret the one-year limit somewhat differently. The Court stated that this time period begins when the prosecutor gets the result from the new DNA analysis; see Supreme Court, decision, 17 December 2020, reference number Ö 936-20, paras. 8-9.

52. See Ds 2018:19. Note that the age of criminal responsibility is fifteen in Sweden (Swedish Penal Code, Chapter 1 Section 6) and that Sweden applies a reduced sentence for juveniles, available for offenders who at the time of the crime were fifteen years old but under twenty-one years old (Swedish Penal Code, Chapter 29 Section 7 para. 1). No offender 
criticised on the grounds that it is not necessary since it is already covered by the current provision. ${ }^{53}$ Further, an application for exoneration to the disadvantage is designed for cases where someone in the original trial was acquitted; the proposed amendment is based only on adjusting the sentencing, which diverges from the rationale and the systematics of the provision. ${ }^{54}$

\subsection{Procedure for Revision in Cases of Exoneration}

The procedure for an application for exoneration is the same regardless of whether the application was filed by a previously convicted defendant or by the prosecutor. Further, except for the aforementioned one-year limitation, the same procedural rules apply regardless of whether the application is to the benefit or to the disadvantage of the defendant.

Only a written application can be considered (Spedish Code of Fudicial Procedure, Chapter 58 Section 4 para. 1), and it should be submitted to a court. If the judgment was pronounced by a district court, the application should be submitted to the (relevant) court of appeal, and if by a court of appeal, it should be submitted to the Supreme Court (Smedish Code of Fudicial Procedure, Chapter 58 Section 4 para. 1). ${ }^{55}$ The latter also applies if the judgment was pronounced by the Supreme Court. The court procedure is only written. However, if found necessary for the investigation, the court can decide that a party or a third party should be examined. ${ }^{56}$ However, this rarely occurs.

As mentioned earlier, the application can be filed either by a previously convicted defendant or by the prosecutor. When the prosecutor files, any general prosecutor can apply to the court of appeal. However, if an application needs to be filed to the Supreme Court, the Prose-

under the age of twenty-one can be sentenced to life imprisonment (Swedish Penal Code, Chapter 29 Section 7 para. 2). However, a governmental inquiry has proposed that the reduced sentence for juveniles over the age of eighteen should be abolished; see SOU 2018:85. Currently (mid-February 2021), neither the proposal on amending the provisions on exoneration nor the proposal on abolishing the reduced sentence for juveniles has (yet) resulted in an amendment of the law.

53. See, e.g., Supreme Court case NJA 2020 s. 134, where the Court granted an application for exoneration in favour of the applicant, since the Court concluded that the applicant was probably younger than what was assumed at the original trial.

54. See the consultation response from the Faculty of Law, Stockholm University, 26 September 2018, available at www.regeringen.se/ 4a7b38/contentassets/3192961dcccc41bd9c812275643f1cc2/ stockholms-universitet-juridiska-fakultetsnamnden.pdf (last visited 17 February 2021). See also the consultation response from the Swedish Bar Association, 26 September 2018, available at www.regeringen.se/4a7b38/contentassets/ 3192961dcccc41bd9c812275643f1cc2/sveriges-advokatsamfund.pdf (last visited 17 February 2021).

55. As a main rule, when the Supreme Court decides whether the application for exoneration should be granted, at least five justices of the Supreme Court must participate (the Swedish Code of Judicial Procedure, Chapter 3 Section 5 para. 1 point 5). The main rule for the court of appeal is that three legally trained judges must participate in the decision (the Swedish Code of Judicial Procedure, Chapter 2 Section 4 para. 1)

56. The Swedish Code of Judicial Procedure, Chapter 58 Section 6 para. 2, Chapter 56 Section 11 para. 1 and Chapter 52 Section 11 para. 1. cutor General must file the petition. ${ }^{57}$ Note that Swedish law allows for the prosecutor and the Prosecutor General to file an application for exoneration in favour of a defendant who has previously been convicted.

When filing an application for exoneration, the applicant must specify the challenged judgment, the basis of and supporting reasons for the application, the evidence that the applicant desires to invoke and what he or she seeks to prove with each particular item of evidence (Smedish Code of Fudicial Procedure, Chapter 58 Section 5 para. 1).

An application for exoneration cannot be granted unless it has been served upon the opposing party, who will be directed to file a written explanation in relation to the application. However, if the opposing party is the prosecutor, the application can be forwarded to the prosecutor without service (Smedish Code of Fudicial Procedure, Chapter 58 Section 6 para. 1). The court can immediately reject an unfounded application and can dismiss an application without notifying the opposing party (Smedish Code of Fudicial Procedure, Chapter 58 Section 6 para. 1).

Additionally, Swedish law requires that the prosecutor must, in certain situations, resume the pre-trial investigation. These rules were introduced into Swedish law in 2012. ${ }^{58}$ First, this shall be done if an application for exoneration contains new evidence or new circumstances not previously presented and if it is probable that there exists a legal ground for exoneration (Smedish Code of Fudicial Procedure, Chapter 58 Section 6A). A pre-trial investigation should not be resumed if there is no need for investigative measures. Secondly, the court that decides whether the application should be granted can order the prosecutor to take certain investigative actions. This requires that the mentioned prerequisites are fulfilled. The court can decide that an ongoing pretrial investigation should also include an inquiry concerning the previous defendant's participation in the crime (Spedish Code of Fudicial Procedure, Chapter 58 Section 6B). Alongside these provisions, the previous defendant should be provided with a defence counsel if a pre-trial investigation is resumed according to these provisions (Smedish Code of Fudicial Procedure, Chapter 21 Section $3 \mathrm{~B})$.

If an application for exoneration is denied, the binding effect of the judgment will remain in force, ${ }^{59}$ and, thus, the outcome of the final verdict will be upheld. However, Swedish law does not limit the number of times an application for exoneration can be filed..$^{60}$

57. It follows from the Swedish Code of Judicial Procedure, Chapter $7 \mathrm{Sec}$ tion 4 para. 3, that the Prosecutor General is the public prosecutor at the Supreme Court.

58. See, further, the travaux préparatoires: prop. 2011/12:156

59. On the matter of the binding effect of the judgment, see Section 2.1.2.

60. This is also possible if an application for exoneration is granted and a new trial is held but the outcome of the new trial confirms the original judgment. Although this is highly unusual, there are cases that illustrate this possibility. One example is that of Bertil Ströberg, who, in 1983, was convicted of gross espionage. He claimed that he was wrongfully convicted and applied several times for exoneration. The Swedish Supreme Court granted one application in 1988, but the new trial, in 
If an application for exoneration is approved, the case is reopened, and the already decided case is brought before a court again. However, approval of an application for exoneration does not quash the original and final judgment. Instead, approval means that the binding effect of the original and final judgment no longer prevents the case from being reopened and being decided anew by a court. ${ }^{61}$ Therefore one might claim that since a decision to approve an application for exoneration results in a review of the case, it resembles an appeal. ${ }^{62}$

An approved application should, as a main rule, result in a new trial. This should be held at the court that last adjudicated in the case (Smedish Code of Fudicial Procedure, Chapter 58 Section 7 para. 1). Until a new judgment has been pronounced, the original judgment is still valid. Consequently, a person who has previously been convicted and sentenced to jail will continue to serve time in prison until a new judgment has been pronounced. 63

From the main rule it follows that the court trying the case again should hold a new main hearing. However, if the main hearing includes comprehensive verbal evidence, the case may be remanded to a lower court. Thus, a new trial intended for the court of appeal may be remanded to the district court. The main hearing will then take place at the district court, which will then pronounce a judgment, which can, of course, be appealed against according to the standard procedure.

When a case is reopened and a new trial is being held, the case is reviewed in full. ${ }^{64}$ According to the standard procedure, all aspects (i.e. guilt, evaluation of evidence, sentence) of the previous judgment are reviewed. In the majority of granted applications for exoneration, the case as such is reviewed. Yet there are cases where an application for exoneration is granted partly, e.g. if the original judgment concerned several offences, but the (approved) application concerned only one of them. Additionally, when granting an application for exoneration, the court can limit the extent of what is being reviewed. It is therefore possible that a review covers only the sentence, not the question of whether the defendant was guilty. ${ }^{65}$

However, as an exception, the court approving the application for exoneration may instead - where the application was filed for the benefit of the defendant change the original judgment immediately. The prerequisite for changing the original judgment by, for

1989, at the court of appeal ended in a guilty verdict. In 2009, Ströberg again filed an application, but the Supreme Court turned this down in 2011.

61. This follows from the Swedish Code of Judicial Procedure, Chapter 58 Section 7 para. 1. See also the travaux préparatoires: SOU 1938:44, at 578.

62. See, e.g., Ekelöf and Edelstam, above n. 29, at 196.

63. However, according to the Swedish Code of Judicial Procedure, Chapter 58 Section 6 para. 3, the court may inhibit the enforcement of the judgment.

64. This follows from the wording of the Swedish Code of Judicial Procedure, Chapter 58 Section 7 para. 1.

65. See, e.g., Supreme Court case NJA 1976 s. 288, where the application for exoneration was granted part in the sense that the review only concerned the sentence. example, dismissing the action is that "the matter is found to be obvious" (Spedish Code of Fudicial Procedure, Chapter 58 Section 7 para. 1). It is highly unusual for a court to find the matter 'obvious', and a majority of approved applications for exoneration will proceed according to the main rule. ${ }^{66}$

\section{Revision in Practice}

\subsection{Official Statistics on the Number of Applications for Exoneration Is Not Available}

While some countries, for example Norway, ${ }^{67}$ provide official statistics concerning the procedure of post-conviction review processes, there are no official statistics concerning how the Swedish criminal justice system operationalises, inter alia, applications for exoneration. ${ }^{68}$ Although official statistics on this matter are not available or presented in a synthesised manner, there is a way to assess the number and characteristics of applications handled within the Swedish criminal justice system, namely by simply asking the courts to provide all the case files concerning application for exoneration. This is, of course, time-consuming since it requires collecting the applications and analysing them in detail. ${ }^{69}$ For these reasons, empirical data on the number of applications that pass through the Swedish courts has not been gathered for the present review. However, a study published in 2017 presented empirical data from one year (2015). ${ }^{70}$

That study found that 383 applications were decided by the Supreme Court and the courts of appeal. For

66. See, e.g., the travaux préparatoires: SOU 2015:52, at 66.

67. See the Norwegian Criminal Cases Review Commission (Kommisjonen for gienopptakelse av straffesaker), which annually presents empirical data on the post-conviction review process in Norway. In 2019 the Norwegian Commission received 153 applications to reopen cases and a total of 131 cases were concluded. The Commission reopened 11 cases, which represent an approval rate of $9 \%$; see the Norwegian Commission's Annual Report 2019, available in English at www.gjenopptakelse.no/fileadmin/user_upload/

Aarsrapport_2019_engelsk.pdf (last visited 17 February 2021), at 3. Note that the approval rate of reopened cases for all the years in which the Commission has existed is $15 \%$.

68. Previously, it was easier to obtain official statistics. Until 1988 an application for exoneration had to be filed to the Swedish Supreme Court, regardless of which court had pronounced the judgment. This made it possible to gather statistics from the Supreme Court. A project initiated by the Office of the Chancellor of Justice showed that between 1950 and 1988, 40-60 applications for exoneration every ten years were approved. The most common legal ground for approving an application was new evidence or new circumstances; see Felaktigt dömda. Rapport från JK:S rättssäkerhetsprojekt (2006), at 96, 103-15. See also Cars, above n. 8, at 316-19, who provides statistics between 1935 and 1958 and who illustrates figures almost similar to the above. See also the travaux préparatoires: prop. 1939:307, Ann. D, at 55, showing that between 1936 and 1938 very few applications for exoneration were granted each year. Thus, during the period when the Supreme Court was the only court instance handling applications for exoneration, the approval rate seems to be rather consistent.

69. However, the problems in gathering the relevant case files are far more complicated; see, further, Hellqvist, above n. 9, at 149-50.

70. Ibid., at 131-53. 
reasons explained further in the study, some applications were excluded, ${ }^{71}$ leaving a detailed analysis of 216 applications. The result was that, of these, "209 applications were rejected and seven applications were approved. This represents a 3\% approval rate". ${ }^{72}$ The Supreme Court decided on a majority of the applications $(79 \%)^{73}$ and the most common invoked legal ground being new evidence or new circumstances. ${ }^{74}$ The study also showed that the characteristics of the seven approved applications were rather disparate: two concerned road traffic offences, two concerned driving under the influence of narcotics or alcohol, one assault, one tax offences and false accounting offences, and one concerned involuntary manslaughter. ${ }^{75}$

Although the study examined the number of applications and their characteristics during only one year, thus raising questions of representativeness, it provides some information on the number of applications that pass through the Swedish courts. Lacking other available data, it provides an important insight in regard to the number, the characteristics and the outcome of the review process in these cases.

\subsection{Examples of Granted Applications for Exoneration from Swedish Case Law}

From the previous sections, it is evident that Swedish law restrictively allows the court to grant an application for exoneration. Since there is a lack of official data and a narrow scope for granting an application, this section will highlight some examples of successful applications. Since very few applications are granted annually, it is difficult to find representative cases. In order to illustrate successful applications, this section reviews three cases. It should be noted that they have some common features. The three applicants were originally convicted of murder. Further, these cases could be viewed as high-profile cases, well known to both lawyers and the general public in Sweden. In two of the cases, the applicants had previously, unsuccessfully, applied for exoneration.

A case worth mentioning is the one concerning Samir Sabri, who at the age of fifteen confessed to the murder of his stepmother. He was convicted by a district court in 1986, and the guilty verdict was based on his confession. ${ }^{76} \mathrm{He}$ was sentenced to institutional psychiatric care. Although he withdrew his confession a few years later, an application for exoneration was filed in 2015 to the Svea Court of Appeal. At the same time, the pre-trial investigation was reopened. The invoked legal ground was new circumstances and evidence, which consisted of the withdrawal of the confession, some new witness testimony and evidence suggesting that the forensic evidence presented at the 1986 trial - for example, the pres-

71. Ibid., at 139-40.

72. Ibid., at 141

73. Ibid., at 141 .

74. Ibid., at 142. Note that in eighty-one of the applications no legal ground or an unclear ground was made.

75. Ibid., at 143-4, 145-8.

76. Stockholm District Court, judgment, 1 October 1986, reference number B 322-86. ence and locations of bloodstains on his clothes - was not compatible with Samir's confession. Additionally, he now stated that his father committed the murder and that his father told him to confess. Samir claimed that his father compelled him to confess so that the father would not be indicted and thereby risk a jail sentence.

In 2016, Svea Court of Appeal granted the application, although it stated that a modified statement from a previously convicted defendant should generally be assessed with some caution. The court emphasised that the withdrawal of the confession and the modified statement were supported by new forensic evidence and in line with witness testimonies. ${ }^{77}$ Following the standard procedure, a new trial was held at the district court, which found Samir not guilty. ${ }^{78}$

Another example of a successful application is the case of Esa Teittinen, who had allegedly killed his seventyyear-old friend by drowning him in a bathtub. Although no crime scene investigation was conducted and it was not possible to identify the cause of death, Esa was, in 2010 , convicted of murder by an appeals court and was sentenced to fifteen years in prison. ${ }^{79} \mathrm{He}$ filed the first application for exoneration in 2014, but the Supreme Court did not grant this application.$^{80} \mathrm{~A}$ second application was filed in 2017.

The previous application consisted of statements from scientific experts, concluding that the original forensic medical examination was faulty and that the cause of death was still unclear. In the second application similar statements, providing the same conclusions, supported the new application. A new reconstruction, presenting an alternative course of events, was also attached to the application. The new reconstruction used figures of similar height and weight to the victim's and Esa's. A bathtub of the same size as in the victim's flat was used. From this, it could not be excluded that the victim could have drowned without external force from another person. The new reconstruction was presented in both a film and in photographs shot from different angles. At the original trial, a reconstruction had also been presented. However, that reconstruction was only presented in two photographs (of bad quality), and the figure playing the victim was heavier than the victim. Thus, the original reconstruction was faulty in several regards.

In 2018, the Supreme Court approved the 2017 application. The court stated that the experts in the second application presented the same conclusions as in the first application. Since the conclusions did not differ from the first application, it could not be considered as new evidence. ${ }^{81}$ However, the Court concluded that the

77. Svea Court of Appeal, decision, 7 April 2016, reference number Ö 7110-15.

78. Stockholm District Court, judgment, 13 December 2016, reference number B 4343-16.

79. Svea Court of Appeal, judgment, 21 October 2010, reference number B 6903-10.

80. Supreme Court, decision, 4 September 2014, reference number Ö 2666-14.

81. Supreme Court, decision, 21 March 2018, reference number Ö 4066-17, paras. 30-2 
new reconstruction was considered new evidence. The Court also emphasised that the new reconstruction raised questions about the conclusions drawn from the original reconstruction. The Court also stated that the case contained peculiar circumstances, and it raised concerns regarding the rule of law. It concluded that 'extraordinary reasons' warranted a new trial. Thus, the Court approved the application based on the supplement rule (see Section 2.2) ${ }^{82}$ Following standard procedure, a new trial was held at the appeals court, which found Esa not guilty. ${ }^{83}$

The third successful case is the one of Kaj Linna. He was convicted, in 2005, of one case of murder, one case of gross robbery and one case of theft. The crime occurred at the home of two brothers. The appeals court sentenced him to life imprisonment. ${ }^{84}$ The conviction depended largely on the testimony of one witness. The witness claimed that Kaj had said that he was planning a robbery of the two brothers' home. He also claimed that Kaj and himself, the day before the crime, drove near the two brothers' home intending to prevent Kaj from committing a crime. The evidence in the original trial further consisted of an analysis of the telephone traffic between, inter alia, Kaj and the witness.

Kaj had previously filed two unsuccessful applications for exoneration to the Supreme Court. ${ }^{85}$ A third application was filed in 2015. To understand the third application, it is necessary to summarise the previous applications.

The first application emphasised that analysis of the witness's telephone traffic showed no connection to a base station near the two brothers' home on the date and at the time that the witness claimed that he and Kaj were driving there. The Supreme Court noted that this evidence supported the unlikelihood that the witness was where he claimed to be. The Supreme Court concluded that the court of appeal did not seem to have assessed this circumstance at the original trial. It was thus not a circumstance affecting the original outcome. ${ }^{86}$ In the decision on the second application, the Supreme Court stated that the Court's 2006 decision was that the matter of the telephone connections was insignificant in relation to the outcome of the original trial. Kaj also presented a reconstruction of the course of events. The Court concluded that both the previous and the new evidence gave no reason to approve the application. However, two of five justices of the Supreme Court dissented, concluding that there were indeed 'extraordinary reasons' to warrant a new trial. The main reason was

82. Supreme Court, decision, 21 March 2018, reference number Ö 4066-17, paras. 33-8.

83. Svea Court of Appeal, judgment, 7 September 2018, reference number B 2860-18.

84. Upper Norrland Court of Appeal, judgment, 1 March 2005, reference number B 49-05.

85. Supreme Court, decision, 5 December 2006, reference number Ö 2734-06; Supreme Court, decision, 21 October 2010, reference number Ö 1797-09.

86. Supreme Court, decision, 5 December 2006, reference number Ö 2734-06. that the conviction relied heavily on the testimony of one witness, whose credibility could be questioned. ${ }^{87}$

The third application presented new circumstances consisting of contradicting the testimony of the witness from the original trial. The witness had to journalists provided new information, which differed from what the witness stated at the original trial. The new information from the witness had been recorded. The new information gave a rather different explanation to what and when crucial events had occurred. Other new evidence that was used to support this application was a comparison with another case of robbery where the victim was killed.

The Supreme Court held that the new evidence concerning the witness raised questions of his credibility, but the Court stated that the statement from the witness now made to journalists was - both when assessed solely by itself and together with the previous applications not enough to grant the application. Yet the Court stated that the "circumstances of the case is rather peculiar" and that the previous applications (also) contained evidence that could question the credibility of the witness. However, considering that a minority of the judges in the second application assessed that the application should be granted, a minor addition of new evidence could be sufficient to grant the application. Thus, the Supreme Court concluded that 'extraordinary reasons' warranted a new trial. ${ }^{88}$ The Court approved the application based on the supplement rule (see Section 2.2). Following standard procedure, a new trial was held at the appeals court, which resulted in an acquittal. ${ }^{89} \mathrm{Kaj}$ Linna spent 13 years in prison. Until the present day, this is the longest time a person, who was later exonerated, has been imprisoned in Sweden.

One feature deserving some discussion is the multiple applications, and the Kaj Linna case is particularly interesting in this regard. An examination of the third application would show that it was supported mainly by successive (new) circumstances, most of which were already known in the two previous unsuccessful applications. Except from again, but with some new evidence, questioning the credibility of the witness, the third application did not really invoke any new evidence. A possible explanation for the Supreme Court's approval could be that the Court considered that the questioning of the credibility of the witness - in the light of what had been invoked in the previous applications - was considered new. Therefore, what was now presented was the straw that broke the camel's back. Yet when approving the third application, the Supreme Court emphasised that what the witness had stated to journalists was not enough to grant the application. Thus, it is rather peculiar that the Court rejected the only new evidence, and it seems that the previous applications

87. Supreme Court, decision, 21 October 2010, reference number Ö 1797-09.

88. Supreme Court, decision, 29 December 2016, reference number Ö 45257-15, paras. 17-24.

89. Upper Norrland Court of Appeal, judgment, 15 June 2017, reference number B 1138-16. 
had a greater impact on the Court's approval rather than the new evidence invoked.

Moreover, a key factor in these three successful applications, eventually resulting in an acquittal, seems to be the involvement of (both) journalists and lawyers. The Samir Sabri case was scrutinised by both a journalist and a lawyer, ${ }^{90}$ the Kaj Linna case had been scrutinised more than ten years prior to the new trial by a journalist who was later followed by other investigative journalists. ${ }^{91}$ And several lawyers were engaged in the different applications for exoneration. The Esa Teittinen case received some media attention; however, it was not scrutinised by journalists in the same way as the two other cases, and the successful application depended entirely on the work of lawyers. ${ }^{92}$ The three cases illustrate that a successful application seemingly depends on having access to proper resources - preferably a combination of investigative journalists and engaging lawyers.

\section{Challenges in the Current Swedish Model of Administering Applications for Exoneration}

A challenge concerning the post-conviction review process in Sweden is the lack of official statistics. It has been pointed out that this limits the understanding of how the Swedish justice system operates when administrating applications for exoneration. ${ }^{93}$ It should be noted that Sweden does maintain official data on other aspects of the Swedish criminal justice systems; for example, the Swedish National Council for Crime Prevention collects data and continuously publishes statistics on reported crimes. The Council also offers statistics on the number of indicted persons and data on different offences. Thus, it is rather peculiar that Sweden does not offer statistics on the post-conviction review process. $^{94}$

90. See above n. 4

91. The first journalist to investigate the case more deeply (in 2006) was Stefan Lisinski at Dagens Nyheter; he kept examining the case during the entire process. In 2015, the journalists Anton Berg and Martin Johnson examined the case in detail in their podcast 'Spår' and found new evidence.

92. The journalist Katarina Lagerwall at Dagens Nyheter was contacted by Esa Teittinen in May 2017, and in July 2017 she wrote a longer article, examining the case, and the second application for exoneration was filed in August 2017. After the approval, she continued to write about the case.

93. Hellqvist, above n. 9, at 149-50. See also S. Hellqvist and M. Lidén, 'Det behövs mer kunskap om resning i brottmål', Dagens Nyheter Debatt, 14 January 2017.

94. Note that the problem is not that it is impossible to collect data from the courts. As Hellqvist points out, there are several practical problems for someone who wants to present official statistics. For example, the data must be collected at several courts, which categorise the applications differently. Another issue is that the courts differ in their archiving procedures. See Hellqvist, above n. 9, at 149.
Providing statistics on this matter is important, since it is a way of removing the current 'blank spot'. Doing so would also be the beginning of more in-depth research, where the statistics on the post-conviction review process (including exoneration) could be scrutinised in detail. It would allow researchers to, inter alia, analyse variations in the number of granted cases and explain long-term variations in the administration of applications for exoneration. Another important aspect to analyse would be whether there is a correlation between the current criminal law policy and the characteristics of the granted applications for exoneration. Yet another reason to provide for official statistics is that it would enable comparative studies, in which variations between jurisdictions with different legal cultures and different core characteristics in their criminal justice system can be analysed further. ${ }^{95}$

When reviewing the application procedure, one feature deserving critique is that an approved application will result in a reopening of the case and a new trial, which shall be held at the court that last adjudicated in the case. From the applicant's perspective, this might seem problematic, since this court originally convicted the applicant. Therefore, an applicant might perceive that the court in which the new trial is being held - to some extent - is biased. This could, of course, be solved by, for example, introducing a new rule stating that the reopened case should be referred to a different court than the one that last adjudicated the case. ${ }^{96}$

A related issue is that the Supreme Court administers and decides on a majority of the applications for exoneration. ${ }^{97}$ This means that an appeals court adjudicated the case. One can assume that the judgment is often appealed against. However, the Swedish Supreme Court is a court of precedent and adjudicates only if the Court has granted an application for a review permit. ${ }^{98}$ Within the ordinary proceedings, the Court may grant a review permit if there exist grounds for exoneration (Smedish Code of Fudicial Procedure, Chapter 54 Section 10 para. 1). ${ }^{99}$ From the applicant's perspective, this might seem problematic, since it might be perceived as the

95. See, e.g., M. Killias, 'Errors Occur Everywhere - But Not at the Same Frequency: The Role of Procedural Systems in Wrongful Convictions', in R.C. Huff and M. Killias (eds.), Wrongful Convictions and Miscarriages of Justice. Causes and Remedies in North American and European Criminal Justice Systems (2013) 61. Killias seems to suggest that the differences between the core characteristics of various criminal justice systems might offer one explanation of why the numbers of (granted) applications for exoneration vary. Thus, one cannot focus solely on extraordinary legal remedies when comparing different jurisdictions; one also needs to consider the legal culture and the core characteristics of various countries.

96. See, for example, the Norwegian Criminal Procedure Act, Section 400

97. See Section 3.1

98. Annually, the Court approves only approximately $2 \%$ of these applications. On the role and function of the Swedish Supreme Court, see, e.g., Welamson and Munck, above n. 29, at 129-67.

99. The Supreme Court rarely grants a review permit based on extraordinary reasons, such as exoneration. See, however, Supreme Court case NJA 2019 s. 438, where the Court (within an ordinary appeal) granted a review permit on the grounds that there existed reasons to approve an application for exoneration to the disadvantage of the defendant. New evidence and new circumstances had been discovered after the pro- 
Court - in its decision not to grant a review permit thereby also having decided on the issue of exoneration. Thus, if a previously convicted person later files an application for exoneration, the applicant might presume that the Court has already positioned itself in this regard. Note that no specific provision hinders, for example, a justice of the Supreme Court that participated in the decision not to grant a review permit from later participating in the decision on whether to grant the application for exoneration. ${ }^{100}$ This could also - again from the applicant's perspective - be perceived as the Court not being objective when administering an application for exoneration. Although some applicants might perceive this procedure as somewhat biased, it is, of course, a positive feature that the Supreme Court within the ordinary procedure might grant a review permit owing to the existence of grounds for exoneration. Thereby, wrongful convictions could be corrected efficiently within the ordinary procedure. But this does not solve the situation where a justice of the Supreme Court has participated in the decision not to grant a review permit and later participates in the decision concerning exoneration. This issue could be addressed by introducing a main rule that hinders a justice of the Supreme Court from, later, also deciding whether to grant an application for exoneration.

Another challenge with the post-conviction review process in Sweden is that a convicted person applying for exoneration seemingly needs to have access to resources. From the cases mentioned in Section 3.2, one could claim that a successful application depends largely on the involvement of lawyers and journalists. ${ }^{101}$ Although it should be emphasised that the number of cases mentioned earlier, in Section 3.2, is low, it is evident that a key factor in each of these cases was the involvement of both lawyers and journalists. One could, of course, argue that the limited number of cases cannot be enough to draw general conclusions from them. Yet one has to remember that only a handful of applications for exon-

ceedings at the court of appeal but before the binding effect of the judgment entered.

100. However, if it is a question of multiple applications for, inter alia, exoneration, the Swedish Code of Judicial Procedure, Chapter 3 Section 7, provides against the participation of a justice of the Supreme Court in a decision on whether to grant a renewed application for exoneration. Note that this applies if "a sufficient number of justices is nevertheless available in the Court". This provision should be viewed as making it possible for a justice of the Supreme Court that decided on the matter of the review permit to participate in the decision on exoneration. However, it follows from general rules and principles that a judge should avoid handling a case that he or she has already dealt with. For related case law on the matter of multiple applications for exoneration, see, further, Supreme Court case NJA 1986 s. 666.

101. Note that the involvement of journalists does not necessarily result in an approval of an application for exoneration. In 2019 the case of Son Do was examined by the journalists Anton Berg and Martin Johnson in their podcast 'Spår'. The defendant was convicted of murder in 2006 and was sentenced by an appeals court to life imprisonment. The journalists found new circumstances concerning, inter alia, the photo confrontation and the interrogation of a child who was the key witness in the case. In 2020, the Supreme Court rejected the application for exoneration, stating - without further reasoning - that no legal ground for exoneration existed in the case; see Supreme Court, decision, 9 December 2020, reference number Ö 5104-19. erations are granted annually. Thus, it is generally a problem to present a number of cases from which general conclusions can be drawn. Further, in all of the cases presented in Section 3.2 the indictment concerned murder. One could argue that the legal safeguards put in place are particularly crucial when the defendant is charged with a serious offence. Therefore, it is worth highlighting that when the indictment concerns a serious offence, a successful application seems to require access to resources.

From the cases reviewed in Section 3.2, it seems that a person claiming that he or she is wrongfully convicted, in order to file a successful application, (first) needs to engage a journalist who scrutinises the previous conviction in detail, which can later be used in the formal application for exoneration written by a lawyer. Generally, a lawyer does not necessarily have the means and time to fully investigate the previous case in detail. Thus, the lawyer does not have the means to review the case and create a story in the same way that a journalist can; meanwhile, a journalist does not have the legal skills to put together an application in a way that would adhere to the language of the court. The combination of the work of a journalist and a lawyer is - at least based on the reviewed cases - seemingly needed. Consequently, one could argue that it is almost impossible for an applicant who lacks the resources (i.e. access to a journalist and/or lawyer) to have a fair chance of successfully applying for exoneration. One cannot exclude the possibility that although there exist cases that meet the requirements for granting an application, the applicant has been unable to express him- or herself in the correct legal language. ${ }^{102}$

Although the number of cases presented in Section 3.2 is limited, they concern grave crimes (murder) that arguably - require greater respect for the existing legal safeguards, and in two of the cases several applications were required before the court granted the applications. The combination of these factors is interesting in that it indicates some deficiencies with the current Swedish model of administering applications for exoneration, raising the question whether this model, where an application for exoneration is administered within the court system, should be reformed by introducing a review committee.

Recently, some authors have suggested that Sweden should reform the current model by (at least considering) replacing it with a review committee. ${ }^{103}$ Those in

102. See also Lidén et al., above n. 11, at 353 (footnote 72), who, on scrutinising a number of applications for exoneration, found that 1,014 out of 1,330 (declined) applications were filed without any legal assistance. See also Hellqvist, above n. 9, at 151, concluding that the applicants included in her study showed that a majority of the applications were written by hand and without legal assistance. This illustrates the difficulties in putting together an application that will meet the legal requirements for granting an application for exoneration.

103. See Lidén et al., above n. 11, at 354-6. Others have suggested that official statistics need to be provided first, and, depending on what the official data shows, it could be relevant to consider reforming the current Swedish model of administering applications for exoneration; see Hellqvist, above n. 9, at 153. The demand for an independent organ to 
favour of introducing such a committee often refer to Norway, which established a review committee in 2001. ${ }^{104}$ It should be noted that in the Nordic region, ${ }^{105}$ a legal comparison between the neighbouring countries is rather common. A legal reform in a Nordic country (in any legal area) is commonly inspired or influenced by the regulation in place in another Nordic country. There are, of course, many reasons why comparisons are often made between these countries, but to mention a few, these countries have a similar (legal) culture, a similar law-making process, an emphasis on the written law and where the travaux préparatoires is viewed as an important legal source for the court when interpreting the written law and they are all considered welfare state regimes. Another aspect that promotes inter-Nordic comparisons is the language. The Swedish, Norwegian and Danish languages are similar, and thus legal sources are readable in their original language, thereby (also) making it easier to recognise and understand the terminology used as well as important legal concepts. Further, the Nordic countries cooperate closely in various matters, including criminal procedural law. Thus, for the purposes of the present review, it is worth referencing - albeit briefly - how applications for exoneration are administered in Norway, in particular the level of independence of the Norwegian Criminal Cases Review Commission.

Before turning to the role of the Norwegian Criminal Cases Review Commission, it should be noted that a few high-profile cases, concerning serious offences, prompted the reform that resulted in the creation of the Norwegian Commission. In particular, one (in)famous case - the Liland case - is often referred to as groundbreaking for the introduction of the Norwegian Cases Review Commission. In brief, in 1969 the defendant was convicted for two cases of murder and sentenced for life with 10 years supervision. After his release, he successfully applied for exoneration, and when the case was tried anew at the appeals court, in 1994, it ended in an acquittal. $^{106}$

administer applications for exoneration is not new. As early as in 1937, a member of the Swedish Parliament proposed that Sweden should introduce a system with an independent institution for operating the post-conviction review process. It was proposed that a preparatory committee administer applications for exoneration and forward to the Supreme Court those that it deemed met the criteria for reopening. It was suggested that the committee would apply to the Supreme Court to grant the petition to reopen the case. Further, the Supreme Court would be able to dismiss a petition only for extraordinary reasons. See motion by Vilhelm Lundstedt, Second Chamber of the Parliament, motion nr 98, 1937. The motion did not result in any changes in this regard; see further First Chamber of the Parliament, Opinion nr 9, 1937; SOU 1938:44, at 71-2.

104. For a background, see the Norwegian travaux préparatoires: Ot. prp. nr 70 (2000-2001). The amendment introducing the Norwegian Criminal Cases Review entered into force on 1 January 2004.

105. The Nordic countries consist of Sweden, Denmark, Finland, Norway, Iceland, Greenland, the Faroe Islands and the Åland Islands.

106. For a more thorough review of the Liland case in English, see, e.g., U. Stridbeck and S. Magnussen 'Prevention of Wrongful Convictions: Norwegian Legal Safeguards and the Criminal Cases Review Commission', 80 University of Cincinnati Law Review 1373 (2012), at 1386-1388. Note that the Liland case resulted in a government inquiry
The high-profile cases prompting the reform in Norway could also explain why the main reason for creating the Norwegian Criminal Cases Review Commission was to increase trust in the post-conviction review process. ${ }^{107}$ This is also a valid argument in the Swedish context. A review committee could, for example, provide more transparent guidelines as to how the application should be outlined, ${ }^{108}$ thereby increasing the number of potentially successful applications. Additionally, a review committee could - from the applicant's perspective - be perceived as more objective than a model in which applications for exonerations are administered within the court system. Further, a review committee could - like in Norway - provide official statistics, which would increase the transparency of the review process. Thus, there is a strong call for introducing a review committee in Sweden, in particular since it would significantly improve the transparency of how applications for exoneration are handled.

Although an introduction of a review committee would improve some features of the current Swedish model of administering applications for exoneration, it would not be unproblematic to establish a Swedish review committee. First, it would require an amendment of the Swedish constitution. According to the Instrument of Government, Chapter 11 Section 13, the Supreme Court or another court that is not an administrative court, shall administer an application for exoneration. The key word in this provision is 'court'; since a review committee would not be considered a court, an amendment would be necessary. ${ }^{109}$ Secondly, it raises some principal questions concerning whether a 'system on the side' (a review committee) per se is preferable to one in which

that scrutinised the case, see NOU 1996:15, and several aspects of the case were discussed in the travaux préparatoires which established the Norwegian Criminal Cases Review Commission; see Ot. prp. nr 70 (2000-2001), at 85-97, where the Norwegian government mainly presented, inter alia, some amendments regarding provisions on criminal procedural law.

107. See, e.g., the Norwegian travaux préparatoires: Ot. prp. $\mathrm{nr} 70$ (2000-2001), at 30-2. See also Etterkontroll av kommisjonen for gienopptakelse av straffesaker. Rapport fra arbeidsgruppe for etterkontroll av Gienopptakelseskommisjonen, Justis-og beredskapsdepartementet, 2012, at 114. Generally, the establishment of the Norwegian Criminal Cases Review Commission seems to have been successful; see, e.g., U. Stridbeck and S. Magnussen, 'Opening Potentially Wrongful Convictions - Look to Norway', 58 Criminal Law Quarterly 267 (2012); Stridbeck and Magnussen, above n. 106. For an overview of the regulation of the Norwegian Criminal Cases Review, see E. Keiserud, K.E. Sœther, M. Holmboe, H-P. Jahre, M. Matningsdal \& J.G. Smørdal, Straffeprosessloven. Lov 22. Maj 1981 nr. 25 om rettergangsmåten i straffesaker. Lovkommentar. Bind II (2020), at 1412-1449; J. Andenœs and T-G. Myhrer, Norsk straffeprosess (2009), at 572-86.

108. The Norwegian Criminal Cases Review Commission has a duty to provide guidance for applicants, and it will establish contact with the applicant. The Commission can, inter alia, appoint a defence counsel in supporting the applicant; see the Norwegian Criminal Procedure Act, Section 397.

109. An amendment of the Swedish Constitution requires two identical decisions by the Swedish Parliament. Before the second decision, an election needs to be arranged (Instrument of Government, Chapter 8 Section 14). Note that the election held between the parliamentary decisions need not to be a general election; an extraordinary election is sufficient. The stipulated minimum time frame between the first and second decisions is, nevertheless, nine months. 
the court system reviews itself. This will be discussed in the following paragraphs.

One of the core questions when introducing a review committee in any jurisdiction is to determine its level of independence. ${ }^{110}$ Norway, for example, has established a fully independent review committee in the sense that the Norwegian Criminal Cases Review Commission has the mandate to deem the application admissible, to examine the case, to order the police and the prosecutor to undertake investigative measures and - more importantly - to decide whether the case should be reopened. ${ }^{111}$ If the Norwegian Commission decides to reopen a case, a new trial should be held in a court. Other countries, for example Belgium, have established a review committee that could be categorised as semiindependent. The Belgian Commission de revision en matière pénale can review a case only if the Court of Cassation has determined, inter alia, the admissibility of the case. If deemed admissible, the case is forwarded to the Belgian Commission, which gives an advisory opinion on whether the Court of Cassation should approve the application for exoneration. The final decision is made by the Court. ${ }^{112}$

The examples of the Norwegian and the Belgian Commissions might be used as illustrations to further discuss that the level of independence is associated with some concerns. In the Swedish context, one of the problems with a fully independent review committee would be that its establishment could be perceived as introducing a higher instance than the Supreme Court. ${ }^{113}$ Evidently, this raises constitutional questions in regard to the division of power, since in Sweden a review committee would be considered an administrative authority, not a court. Although Sweden does not have the same tradition as, e.g., some European jurisdictions concerning a strong division of power, it might seem problematic for an administrative authority to review a court of law. However, since the Swedish Constitution is built on the principle of 'people sovereignty',114 the constitutional concerns might not necessarily be problematic. On the contrary, the principle of 'people sovereignty' might even help the case for establishing a review committee. Furthermore, the establishment of the Norwegian Com-

110. For an overview of review committees in various jurisdictions, see, e.g., C. Hoyle and M. Sato, Reasons to Doubt. Wrongful Convictions and the Criminal Cases Review Commission (2019), at 6-11.

111. For example, the Scottish Criminal Cases Review Commission, the Criminal Cases Review Commission for England, Wales and Northern Ireland and the New Zealand Criminal Cases Review Commission could be considered independent in a similar way as the Norwegian Commission, since they can refer a granted application to the court. To the best of the present author's knowledge, the review committees in these jurisdictions decide whether to grant an application, and a successful application will result in a new hearing in a court.

112. See K. Verhesschen and C. Fijnaut, 'Chosen Blindness or a Revelation of the Truth? A New Procedure for Revision in Belgium', Erasmus Law Review, 4 (incomplete), (2020).

113. Cf. e.g. the travaux préparatoires: prop. 1939:307, at 26

114. In Swedish: folksuveränitet, which is expressed in the Instrument of Government, Chapter 1 Section 1 para. 1, stipulating that "All public power in Sweden proceeds from the people." mission has not raised any major concerns in this regard. ${ }^{115}$

Yet a semi-independent review committee also has its disadvantages. Since a court decides whether an application is admissible and makes the final decision on whether to grant an application for exoneration, thereby maintaining control over the question of which cases should be reopened, one might question why it is necessary to establish an organ by the side, and a semi-independent review committee could therefore be perceived as pro forma. The counterargument would be that even though a system with a semi-independent review committee means that a court decides whether to grant the application, a semi-independent review committee would still improve the transparency of the review process. This is perhaps the strongest argument for a semiindependent review committee.

Another pertinent issue in this context is to design the system such that an adequate balance is struck between the principle of firmness and that of truth. ${ }^{116}$ This aspect is particularly interesting since one might assume that the establishment of a review committee would increase the number of applications for exoneration. ${ }^{117}$ First, the existence of a review committee would not necessarily affect the balance between these principles. As long as new legal grounds for exoneration are not adopted, the review committee would apply the existing legal grounds, meaning, inter alia, that prior precedents from the Supreme Court would remain an important legal basis for deciding whether to grant an application for exoneration. Second, even if a review committee were introduced, the principle of firmness would still be predominant. The reason would be mainly systematic: in order for the legal system to be reliable, the outset must be that a legally binding judgment should not be reconsidered (unless the requirements are met for, inter alia, exoneration). However, an independent organ might find the requirements for exoneration to be met in a larger number of applications than previously. That does not mean that the principle of truth has trumped the principle of firmness. Instead, a moderate assumption would be that since the applications would be examined more thoroughly than in the current Swedish model, a slight increase in the number of approved cases could be expected. Ideally, those cases would also have been approved within the current model, but they might not today be given the further examination needed in order to ascertain that they actually meet the criteria for exoneration.

Regardless of the level of independence, the importance of establishing a review committee lies in its mandate to scrutinise cases and applications, particularly in its pow-

115. See, e.g., the Norwegian travaux préparatoires: Ot. prp. $\mathrm{nr} 70$ (2000-2001), at 30, where it was concluded that the establishment of the Norwegian review committee, which is an administrative authority, was not infringing the Norwegian Constitution.

116. See Section 2.1.1.

117. The experience from Norway seems to indicate that the number of applications has been manageable since the Norwegian Commission was established. 
er to mandate the police and the prosecutor to take investigative measures. The prime role and function of a review committee - whether independent or semi-independent - is to ensure that the case is thoroughly examined so that the later decision on whether to grant the application (regardless of the outcome) is based on adequately prepared documentation. Relating to the Swedish context, the main argument for introducing a review committee here is that it would improve the degree of scrutiny and transparency. This is particularly true for applicants who lack the resources that today seem to be necessary in order to adhere to the language of the court. It would also, as in Norway, presumably increase the trust in the Swedish post-conviction review process.

Hence, for the preceding reasons, there is a need to introduce a review committee into Swedish law. However, issues concerning how a review committee in the Swedish context should be designed and the details of its procedure and its level of independence are perhaps beyond the scope of this article. A reform of this kind requires, as always in the Swedish lawmaking process, that the government appoint a committee of inquiry to examine these matters and present a detailed proposal in regard to how the review committee could be modelled.

\section{Conclusions}

Sweden pays great respect to the rule of law and has put several legal safeguards in place, guaranteeing a high level of legal certainty and minimising the risk of wrongful convictions. Generally, the Swedish criminal justice system is robust and reliable. Swedish law further allows for a post-conviction revision in criminal law cases by, inter alia, regulating the possibility to apply for exoneration. Since Swedish law emphasises the importance of the binding effect of a judgment, applications for exoneration are granted only in extremely rare cases. It makes sense that applications are generally dismissed; otherwise, there would be a risk of undermining the reliability of pronounced judgments in criminal law cases. Thus, the present review shows no support for a need to, for example, extend the current legal grounds for invoking an application for exoneration. ${ }^{118}$

However, there are some factors that clearly limit the understanding of how the Swedish justice system actually works when administering applications for exoneration. Therefore, the review suggests that two improvements are needed, concerning mainly the application procedure. First, Sweden should introduce a system that provides for official statistics on this matter. This would enable researchers to analyse the statistics of, for example, granted applications and their characteristics. It would also improve the transparency of the country's criminal justice system. Secondly, the provisions regulating the procedure for exoneration should be reformed, having remained unchanged for almost eighty years. According to the current Swedish model, applications for exoneration are administered within the court system. The time has come to introduce into Swedish law a model where applications for exoneration are administered by a review committee. Although this raises some constitutional concerns relating to, inter alia, the division of power and the committee's level of independence, Sweden has nothing to lose by introducing a model that would further enhance the legal certainty in - and the transparency of - its criminal justice system.

118. Another matter is that the courts interpret an application for exoneration according to the legal standards set out in the written law, while many applicants lack both legal education and legal assistance. Thus, it is assumed that many (almost all) convicted persons write their applications themselves. It is not unusual for an application to consist of handwritten notes, almost impossible to interpret. The lack of legal assistance clearly limits the actual use of the possibility to apply for exoneration. Without legal assistance, it is, of course, difficult to submit an application that the courts will even consider granting; see, further, Hellqvist, above n. 9, at 151; Lidén et al., above n. 11, at 352-3. This question falls without the scope of the present review but merits more scholarly attention. 